\title{
4 Confounding Factors in the Observational Productivity-Diversity Relationship in Forests
}

\author{
M. Vilà, P. Inchausti, J. Vayreda, O. Barrantes, C. Gracia, \\ J. J. IBÁÑEZ, and T. MATA
}

\subsection{Introduction}

Field experiments conducted in randomly assembled grassland communities have demonstrated that changes in plant species diversity affect ecosystem productivity over a range of environmental conditions (Hector et al. 1999; Tilman et al. 2001). However, there is still a controversy as to whether this causal relationship is also found in natural systems (Loreau et al. 2001; Schmid 2002), especially at regional scales (Bengtsson et al. 2002). For example, Troumbis and Memtsas (2000) found that Greek shrub lands were more productive in stands with high shrub diversity. However, the positive correlations between diversity and productivity may be confounded with other less conspicuous or unknown factors such as site quality or fertility that affect both variables and underlie the observed correlation (Huston 1997; Troumbis 2001; Wardle 2001). Furthermore, observational studies have not always found a positive relationship between diversity and productivity. The available evidence shows that multiple patterns exist and change with spatial scale. Exhaustive reviews on the observed relationship between vascular plant species richness and productivity have found that the hump-shaped (unimodal) relationship occurred more often than a monotonically increasing relationship, depending on the geographical scale and ecological organization (e.g., within or across community types; Waide et al. 1999; Mittelbach et al. 2001).

This controversy can be partially reconciled by superposing experimental results on observational patterns (Fig. 4.1). That is, observed diversity-productivity relationships compare diversity across sites of different productivities driven by environmental conditions. The observations (data points) fill the area below a humpbacked line. Instead, experiments compare productivities at different experimentally established levels of diversity at single sites and maintaining all environmental factors influencing productivity constant 


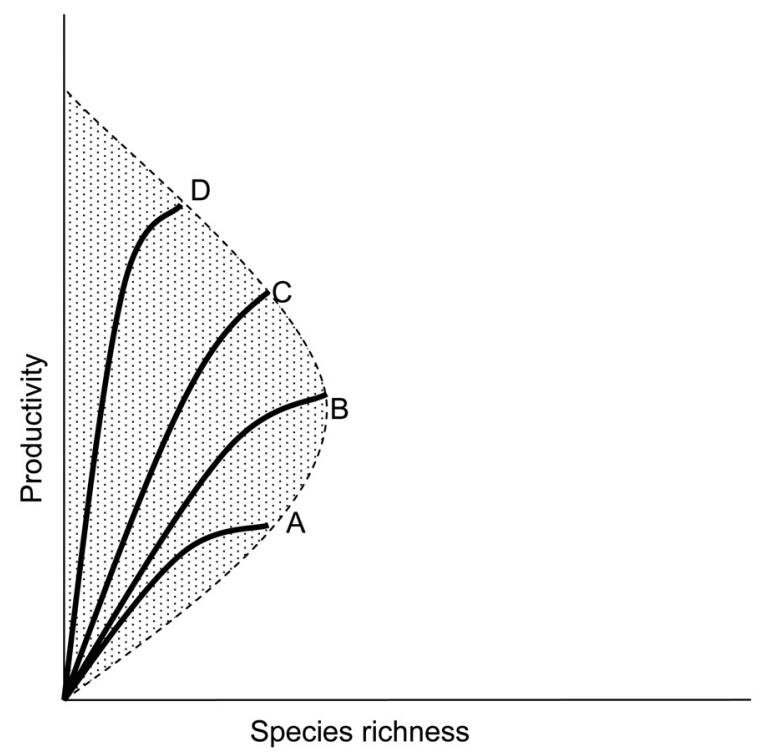

Fig. 4.1. Observed and experimental relationship between species richness and productivity and potential effects of disturbance and silvicultural practices in forests. The observations across sites fill the area below a humpbacked line. The experimental diversity-productivity relationship at specific sites can be represented as different ascending trajectories within the humpbacked area. From the initial $A$ trajectory, $B, C$, and $D$ trajectories indicate potential increasing slopes of the diversity-productivity relationship in a site at early stages of regeneration after disturbance. Sustainable forest management should avoid trajectories D and adopt trajectories B. (Adapted from Bengtsson et al. 2002)

(e.g., the same soil fertility, the same climate, the same topography). The experimental diversity-productivity relationship can be represented as different ascending trajectories within the humpbacked area (Loreau et al. 2001; Bengtsson et al. 2002; Schmid 2002). A rather unexplored issue concerns the mechanisms that underlie the different trajectories and the ecological processes that can shift one trajectory to another (but see Schmid 2002). The purpose of this chapter is to exemplify the difficulties of observational studies that rise while detecting diversity-productivity relationships in forests. Multivariate approaches are needed to separate the effects of covarying causal factors (Waide et al. 1999).

Monospecific forest stands and monocultures of the highly productive tree species have been extremely favored for pulp and timber production (Kelty 1992). At the same time, mixed forests in some regions have been maintained for landscape aesthetics, conservation of wildlife, recreational purposes, higher diversity of produces, and the belief that they are more resistant to disease and to disturbances such as wind or fire (Assman 1970; Kerr et al. 1992; 
Dhôte, Chap. 14, this Vol.; Pautasso et al., Chap. 13, this Vol.; Wirth, Chap. 15, this Vol.). However, the concept of a potential increase in productivity in mixed tree stands has not generally been incorporated into forestry and conservation practice (but see Assman 1970). Recently, Caspersen and Pacala (2001) analyzed the Forest Inventory and Analysis (FIA) database in the United States (more than 20,000 plots) and have found a positive correlation between species richness and stand productivity. However, the lack of environmental description of stands hinders the interpretation of this association. Observational and experimental approaches in forests should examine the relationship between species diversity and productivity while controlling for the effect of other covariant factors that could underlie and confound the diversity-productivity relationship. In the boreal forest, comparisons between monospecific stands and adjacent mixed stands of similar age, tree density, soil characteristics, and management regime have revealed that whether mixed stands are more productive than monospecific stands depends on the identity of the species in the mixture. Mixtures of birch (Betula spp.) with spruce (Picea abies) are more productive than spruce stands, but mixtures of birch with Pinus sylvestris are not more productive than pure pine stands. Furthermore, the stage of stand development is influential: mixtures are more productive than monospecific stands in early stand development but not when trees are more than $17 \mathrm{~m}$ tall (Frivold and Frank 2002). Similarly, a regional survey conducted in Mediterranean forests dominated by Aleppo pine (Pinus halepensis) revealed that monospecific stands have lower wood production than mixed forests (two to five species). However, when climate, successional stage, bedrock type, and radiation were included in the analysis, stand tree-species richness was no longer a significant factor (Vilà et al. 2003).

In this chapter, we discuss some of the factors that can confound the tree diversity-productivity relationship in temperate forests. We stress the role of seral stage, environmental factors, and management as such factors in the observational diversity-productivity relationship. As an example, we present a case study using the Ecological and Forest Inventory of Catalonia (IEFC), a large dataset that supports a positive association between tree species richness and stand stemwood production. Wood production in forests is somehow more relevant than total plant production for evaluating tree growth rates and competition interactions, since it is through the investment in the physical structure of wood (and also roots) that plants compete with one another (Huston 1994). However, we show that factors such as successional stage and climate overwhelm the positive relationship between tree species richness and stand stemwood production. Finally, we discuss the concept that in these forests past management practices are probably the major forces masking the natural patterns of forest diversity and productivity. 


\subsection{Covariant Factors Determining the Forest Diversity-Productivity Relationship}

\subsubsection{Successional Stage}

There are considerable differences in structure and ecosystem functioning between young, mature, and old forests. In even-aged forests, for instance, growth declines after reaching a peak relatively early in a stand's life (which typically coincides with the maximum development of leaf area: Ryan et al. 1997). This decline is thus both size- and age related (Weiner and Thomas 2001). Tree height, diameter, and biomass increase through time while tree density decreases. As growth rates first increase and then decrease with tree size and age, the growth curves typically have a sigmoid shape. The physiological mechanisms causing this decline in the rate of carbon assimilation are related to reduced leaf area and reduced photosynthesis, mainly due to increasing hydraulic resistance in taller and older trees, lower nutrient availability, and maturation changes (Murty and McMurtrie 2000).

Patterns of age-related decline in forest productivity are well known in monospecific forests, but the timing, speed, and magnitude of decline vary between species and site quality (Ryan et al. 1997). However, the dynamics of mixed forests is much less understood and more difficult to predict than in single-species stands, because stand productivity is not only related to population dynamics of the dominant species but also to differences in resource use among species and to competitive interactions.

The age-related decline of tree growth implies that the successional stage also influences tree and forest productivity. Wood production is greater during early successional stages after natural or anthropogenic disturbances such as fire and clear cutting, than in late successional stages when canopy closure and competition typically prevent strong growth responses after disturbance (Whittaker and Woodwell 1969; Bormann and Likens 1979; Vilà et al. 2003).

Plant species diversity also changes during succession. Classically, diversity has been predicted to be higher with time after a disturbance because longer periods of time and spatial heterogeneity may be required in order to allow species to establish. For instance, overstory and understory plant species richness of Douglas fir forests of the Pacific Northwest builds up during succession after clear-cutting or burning in parallel with increasing vertical and horizontal spatial heterogeneity, despite the closure of the tree canopy (Halpern and Spies 1995; Franklin et al. 2002). However, the reverse pattern, more diversity at early and intermediate stages of regeneration than at late stages, can also be found. For example, a long-term analysis of permanent plots in the southern Appalachians (USA) found that, over a period of 14 years, tree diversity was the highest after clear-cutting and declined with 
canopy closure (Elliott and Swank 1994). It is also possible that species richness reaches a plateau and remains largely unchanged afterwards. This could be the situation of highly resilient Mediterranean forests where the same tree species are maintained after fire due to their regeneration strategy, such as the existence of serotinous fruits that open with heating, or of the ability to resprout when aboveground biomass is removed (Trabaud 1987).

Overall, after disturbance, the diversity-productivity relationships might result in different trajectories of ascending slopes (Fig. 4.1). Let us assume that before disturbance, the diversity-productivity relationship within a site is A. At early stages of regeneration after disturbance there can be an increase of the productivity from $\mathrm{A}$ to $\mathrm{B}, \mathrm{C}$, or $\mathrm{D}$ while species richness might increase (B), remain the same (C), or decrease (D). These changes in species richness would depend on the type and severity of the disturbance, the response of plant species to disturbances and colonization by opportunist species establishing through dispersal from nearby non-disturbed areas. Studies conducted in chronosequences of disturbed forests and permanent plots of forests before and after disturbances could elucidate how diversity-productivity relationships differ after disturbances from those before.

\subsubsection{Environmental Correlates}

In observational studies, the species diversity-productivity relationship cannot be easily separated from the effect of site conditions. If we take the unimodal pattern as the most common observed relationship across communities and focus on the ascending portion of the curve, species diversity is highest on sites conducive to high productivity (Huston 1994). In contrast, single species stands are often found in extreme environments. For example, among semi-natural forests in Europe, woods of Pinus uncinata at high altitudes, Quercus petraea in the Atlantic climate of west Britain, Cupressus sempervirens on the south-facing limestone-rocky slopes of Crete, etc. (Rackham 1992). Regional analyses across forests types have found a positive correlation between tree diversity and actual evapotranspiration (Currie and Paquin 1987). Increasing temperature, moisture availability, and soil fertility also favor tree growth. In California, rainfall explains $62 \%$ of the variation of tree species richness (Richerson and Lum 1980). Similar patterns have been found in a whole-country analysis of tree diversity in New Zealand primary forests (Leathwick et al. 1998) wherein tree diversity increased with mean monthly temperature, solar radiation, and soil and atmospheric moisture, which in turn control forest productivity. However, on the descending portion of the curve (i.e., on the higher end of the productive gradient), wherein competition by dominant species reduces the availability of resources to other species, species diversity diminishes with productivity. In fact, within deciduous forest types in nearby humid sites, the relationship between normalized evapo- 
ration and tree richness is negative, possibly because dominant tree functional types or species may dominate the pools of available $\mathrm{N}$ and lower the amount for other tree species (Baldocchi, Chap. 7, this Vol.).

At the local scale, variation in site quality is thought to determine whether mixed forests are more productive than monospecific stands (Assman 1970; Kelty 1992; Pretzsch, Chap. 3, this Vol.). In the simplest case of two-species mixtures, higher productivity of mixed-species stands compared with monospecific stands would be expected whenever the two species are either more efficient or complementary in using limiting resources or when there is facilitation between species. For example, a mixture of an $\mathrm{N}$-fixing tree species and a non- $\mathrm{N}$-fixing tree species will be more productive than the monospecific stands of the component species in poor soils, but we might not expect a mixture advantage in stands with high $\mathrm{N}$ availability. Different light requirements of the species in a mixture may increase productivity in comparison with pure stands. A shade-tolerant understory tree species forming a dense canopy and a low-shade-tolerant overstory deciduous tree species can form stands of higher productivity when mixed than do monospecific stands in a sunny site, though not in a shady site (Kelty 1989).

We should also emphasize that most observational studies comparing productivity between monospecific and mixed-species stands have been carried out in climates where soil moisture is generally not critically limiting to stand productivity (e.g., Cannell et al. 1992; Kelty 1992; Caspersen and Pacala 2001). In regions where water and nutrients are the principal factors limiting stand productivity, we might expect a positive correlation between diversity and productivity, because both variables are limited by the same factors (Waide et al. 1999).

\subsubsection{Management}

Management can mask or alter the expected relationship between species diversity and stand productivity by directly or indirectly enhancing the presence and growth of some forest species and not others. Most monospecific stands in non-extreme environments are the result of human intervention favoring high-producing species. For example, Betula papyrifera stands in north Minnesota are replacing diverse pine forests. Similarly, stands dominated by Pinus palustris in Florida are artificially maintained by forestry practices (Rackham 1992). Monospecific stands can also be achieved by plantations or by deliberate elimination of unwanted species. While oaks were maintained for bark tanning, other accompanying species have been eliminated in Scottish forests after the eighteenth century (Rackham 1992). Conversely, in the same period, deciduous oaks were eliminated from mixed forests in Catalonia (Spain) for its high quality as firewood (Villaescusa 1993). It is well known that selection by grazing and browsing can also decrease tree 
species diversity of some forests. For example, fallow deer (Dama dama) preference in UK can change dominance from Fraxinus to Populus. Similarly, in Spain grazing by sheep and domestic goats can change patterns of woody species composition, diversity, and biomass (Cuartas and García-González 1992).

The species mixtures promoted by foresters (Pretzsch, Chap. 3, this Vol.) have been designed to find the best such mixtures. Therefore, it is not surprising to find that species tree composition is usually more important than tree richness in accounting for stand tree production. Not only might traditional silvicultural practices simplify forest diversity, but also they directly influence forest structure by maintaining even-aged stands, by keeping basal areas constant, or by removing wood. Stand wood production forecasts that do not take into account biomass export underestimate production.

All of these management practices aim mostly at increasing forest productivity over the short or long term. Management can have effects on diversity and productivity similar to those of disturbances. An extensive survey of boreal forests has shown that postlogging stands contain the same plant diversity and stand productivity as do plots burned by natural fires (Reich et al. 2001). This suggests that management practices and disturbances could influence the tree diversity-productivity relationship in the same way. Going back to Fig. 4.1, sustainable forest management should ensure that its structure maintains high diversity and productivity values (trajectory B) and avoids activities that increase sharp slopes of high productivity but low diversity (trajectory D). For example, even though the financial value of Norway spruce is overwhelmingly superior to that of beech, the recreational value, resistance to disturbance risks, and diversity of products are greater in mixed spruce/beech stands than in pure spruce stands (Assman 1970).

\subsection{The Ecological and Forest Inventory of Catalonia (IEFC)}

\subsubsection{Characteristics of the IEFC}

The IEFC (Gracia et al. 2000-2002) is an extensive forestry database comprising information from 10,644 sampling plots of $10 \mathrm{~m}$ radius randomly distributed throughout Catalonia, NE Spain. A subset of these plots $(n=2,107)$ has more of the standard information gathered in a classic forestry survey than found elsewhere, and therefore was the one we used in the analysis. The IFEC includes the customary information of forest inventories and additional data related to functional aspects of forest ecosystems. In each of the 10,644 plots, and for each tree with a diameter at breast height $(\mathrm{DBH})$ above $5 \mathrm{~cm}$, species identities were noted and heights and DBHs measured. In all plots, core incre- 
ments were taken for each representative live tree species (one or more) of a diameter class $>5 \mathrm{~cm}$ to calculate age and annual tree growth over the last 5 years. The overall stemwood production of a plot per year was estimated as $\mathrm{P}=\left(\mathrm{B}_{5}-\mathrm{B}_{0}\right) / 5$, where $\mathrm{B}_{0}$ is the tree plot stemwood biomass per area 5 years before the sampling and $B_{5}$ is the tree plot stemwood biomass per area during the sampling. Stemwood biomass was calculated by common silvicultural methods (see Gracia et al. 2003 for details). We did not include wood production of trees that died during the 5-year period because it was likely negligible. The IEFC does not include wood production of shrubs. Knowing that stemwood production values would underestimate total wood production in our study, an estimation of shrub cover per plot was included in the analysis to control for the effect of the shrub layer on tree stand stemwood production. Catalonia is the second most forested region of Spain (36\% of its area being covered by forests) and the one with the most acute climatic gradient (Gracia et al. 2000-2002). The region covered by the IFEC includes steep regional climatic, geological, and topographic gradients. Catalonia (ca. $31,900 \mathrm{~km}^{2}$ ) is located in northeast of the Iberian Peninsula, bounded on the north by the Pyrenees and on the east by the Mediterranean Sea. Therefore, forests account for a large phytogeographic region, including Mediterranean, Sub-Mediterranean, Eurosiberian, and even Boreoalpine chorologies.

As a preliminary data exploration we tested the relationship between tree species richness (independent variable) and stand tree stemwood production (dependent variable) by ANOVA. We then further explored the effect of tree species richness and several forest structure and environmental parameters on stand tree stemwood production by a general linear model (GLM) analysis, following the JMP package (Anonymous 1992). The GLM analysis gives the significance of the full model (including all parameters) and for each parameter using $F$ tests. A model that included all independent parameters was built for all stands and also for stands dominated by particular species, allowing for an approach across forests and within forests types, respectively.

By means of this approach, a previous analysis of pine forests using the IEFC database indicated that the positive relationship between tree species richness and stand stemwood production is confounded by the influence of macroenvironmental factors and successional stage (Vilà et al. 2003).

\subsubsection{Productivity of Mixed Forests in Catalonia}

Almost three-quarters $(73.3 \%)$ of Catalonian forests are mixed, with tree species richness ranging from two to five species, with a mode of two-species mixtures (29.9\% of plots) and five-species mixtures being the least common (6.2\%). Most dominant species do not form monospecific stands and all the species forming monospecific stands are also present in mixed stands. The IEFC includes observations on 95 tree species distributed into 43 genera. 
Ecological Studies Vol 176, page proofs as of August 2004, Kröner, Heidelberg

Confounding Factors in the Observational Productivity-Diversity Relationship

Table 4.1. Stemwood production (in $\mathrm{t} \mathrm{ha}^{-1}$ year $^{-1}$, mean \pm SE) of the dominant tree species when grown in pure stands and when mixed. and total stemwood production of mixed stands for Catalan forests according to the IEFC

\begin{tabular}{llll}
\hline Dominant species & Pure stands & Dominant sp mixed & Mixed stands \\
\hline Castanea sativa & $4.92 \pm 1.07$ & $2.73 \pm 0.40$ & $2.94 \pm 0.37$ \\
Abies alba & $4.49 \pm 0.88$ & $3.83 \pm 0.40$ & $4.17 \pm 0.48$ \\
Fagus sylvatica & $3.47 \pm 0.54$ & $3.08 \pm 0.22$ & $3.33 \pm 0.23$ \\
Pinus sylvestris & $1.68 \pm 0.09$ & $1.46 \pm 0.04$ & $1.64 \pm 0.05$ \\
Pinus uncinata & $1.48 \pm 0.15$ & $1.50 \pm 0.09$ & $1.95 \pm 0.15$ \\
Pinus nigra & $1.47 \pm 0.15$ & $1.31 \pm 0.06$ & $1.53 \pm 0.06$ \\
Quercus ilex & $1.27 \pm 0.12$ & $1.36 \pm 0.06$ & $1.68 \pm 0.08$ \\
Pinus halepensis & $1.00 \pm 0.07$ & $1.17 \pm 0.04$ & $1.54 \pm 0.06$ \\
Quercus pubescens & $0.80 \pm 0012$ & $1.06 \pm 0.09$ & $1.48 \pm 0.15$ \\
Quercus suber & $0.70 \pm 0.11$ & $0.75 \pm 0.06$ & $0.63 \pm 0.06$ \\
\hline
\end{tabular}

Forty-two of these species are dominant (basal area $>50 \%$ of the total per plot): Pinus halepensis (present in $20 \%$ of sampling plots), Pinus sylvestris (19\%), and Quercus ilex (16\%) being the three most dominant species.

On average, total stand stemwood production is low (mean $\pm \mathrm{SE}=1.65 \pm$ $0.03 \mathrm{t} \mathrm{ha}^{-1}$ year $^{-1}$ ) compared to other temperate forests (http://www.efi.fi/databases/eefr; Tables 14.1 and 14.11 in Huston 1994). Of the ten most dominant species, the most productive species in monospecific stands are Castanea sativa, Abies alba, and Fagus sylvatica. Quercus pubescens and Q. suber are the least productive species (Table 4.1). Dominant species stemwood production was not significantly larger in monocultures than in mixed stands (ANOVA, $\left.F_{4,1971}=0.65, P<0.63\right)$. However, stemwood production of the whole stands was dependent on tree species richness (ANOVA, $F_{4,2076}=8.85, P<0.001$ ). While stands with five species were the most productive, monospecific stands where the least productive (Fig. 4.2A). Due to database constraints we could not analyze which mixture composition has the highest productivity. Therefore, we could not check whether mixed stands produce more than the best species in pure stands, what is known as overyielding (Vandermeer 1989).

\subsubsection{Successional Stage and Other Biotic Correlates}

As mentioned in Section 4.2.1, the effect of species diversity on tree production can be confounded with differences in seral stage that concomitantly influence tree size and vegetation structure. Unfortunately, the IFEC database 

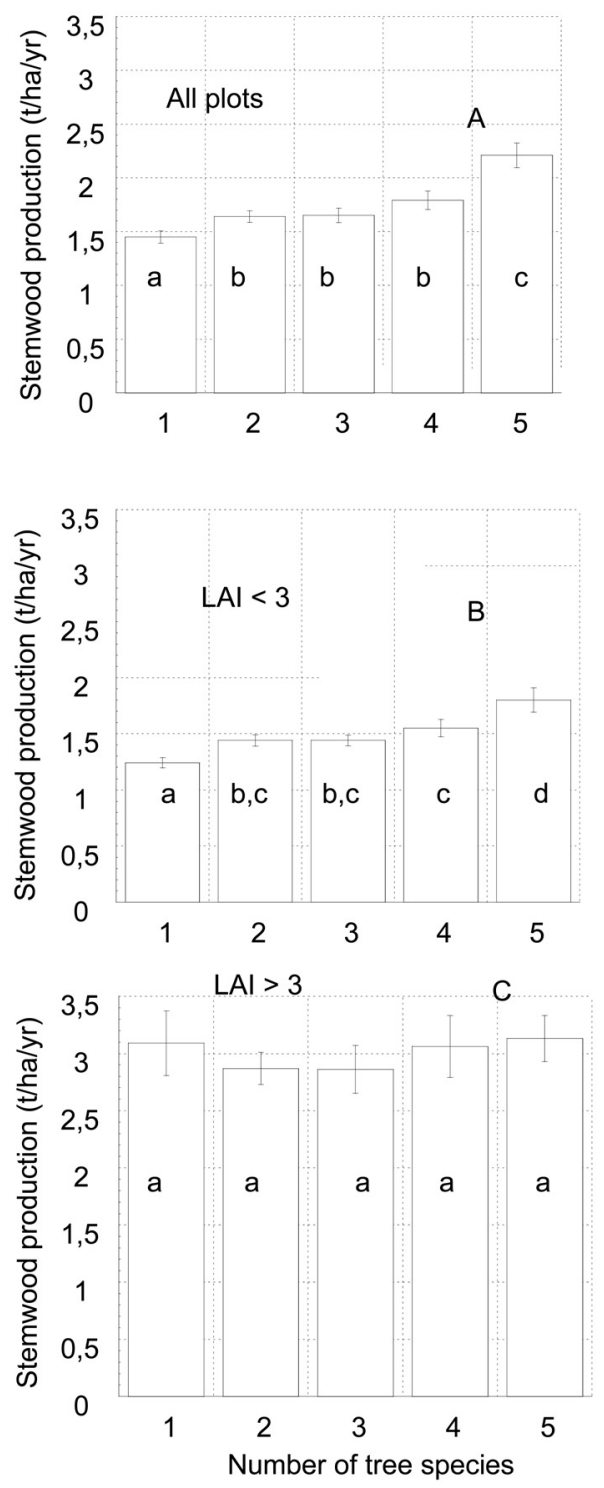

does not contain quantitative or qualitative information on stand age or intervals between disturbances (each followed by regeneration). However, we used the age of the oldest tree sampled as a surrogate of successional stage, and found that this factor had a significant effect on stemwood productivity (Table 4.2). On average, Catalan forest are young, mean \pm SD being $61 \pm 34$ years). Stands with one or two tree species are significantly older than mixed forests with higher species diversity $\left(F_{4,1563}=12.23, P<0.001\right.$; Fig. 4.3).
Fig. 4.2. Mean stand stemwood production $( \pm \mathrm{SE})$ in relation to tree species richplots with $\mathrm{LAI}<3(\mathrm{~B})$, and plots with LAI $>3(\mathrm{C})$. Different lowercase letters indicate significant differences over tree species richness according to Fisher's test ness in Catalonia for all IEFC plots (A), 
Ecological Studies Vol 176, page proofs as of August 2004, Kröner, Heidelberg

Confounding Factors in the Observational Productivity-Diversity Relationship

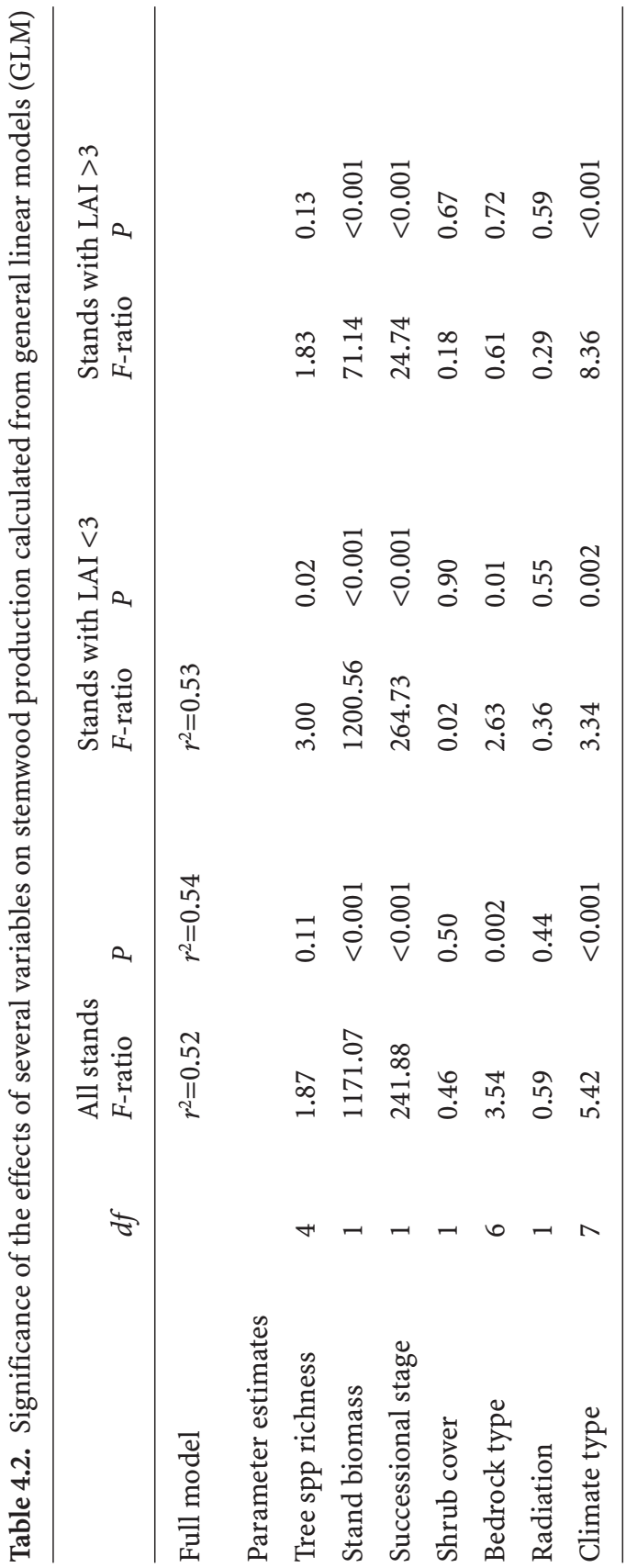




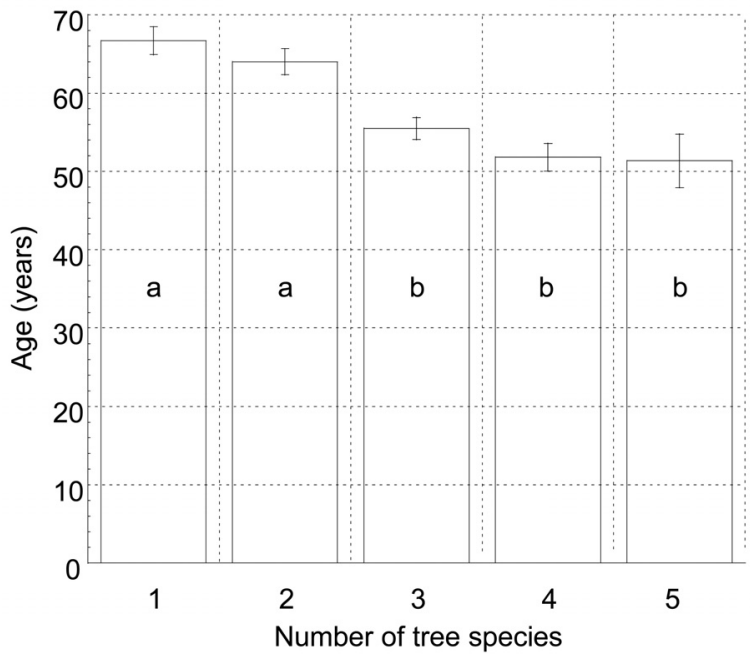

Fig. 4.3. Mean maximum age $( \pm S E)$ of forests of different tree species diversity in Catalonia for all IEFC plots. Different lowercase letters indicate significant differences over tree species richness according to Fisher's test

The oldest forests are almost pure stands of Abies alba (mean \pm SD of $131 \pm 52$ years) and Pinus uncinata (mean \pm SD. $105 \pm 47$ years).

We included total stand stemwood biomass in the analysis as an estimation of wood size and found a significant positive correlation between stemwood biomass and production $\left(\mathrm{r}^{2}=0.42\right)$. This increase in stemwood production with biomass has also been found in other temperate regions. For example, an extensive survey across a 3,300-m altitudinal gradient in the central Himalayas disclosed patterns of forest productivity that matched those of stand biomass (Singh et al. 1994). The positive relationship between forest biomass and productivity indicates that on average these forests have quite open canopies. In fact, the increase in stand stemwood production was found only before canopy closure $(\mathrm{LAI}<3)$. In forests with closed canopies (LAI $>3)$, stand stemwood production did not increase with tree species richness (Fig. 4.2B, C). The same trend was found if tree cover was used in the analysis instead of LAI. Low LAI values might result from young seral stages, environmental constraints (e.g., drought, poor or rocky soils), or silvicultural clearings.

One striking finding was that shrub cover did not modify stand tree stemwood production in any of the conducted analyses (Table 4.2). In Catalan forests variation in shrub layer across forests is large (mean $\pm S D$ is $63.45 \pm 25.40 \%$ ). It was also surprising to find that shrub cover increased with increasing tree richness (ANOVA, $F_{4,2077}=14.20, P<0.001$, Fig. 4.4), suggesting that shrubs do not interfere with tree production and that, at the regional scale, factors leading to higher tree production and tree diversity might also be responsible for a better shrub development. 
Fig. 4.4. Mean shrub cover $( \pm \mathrm{SE})$ of forests of different tree species diversity in Catalonia for all IEFC plots. Different lowercase letters indicate significant differences over tree species richness according to Fisher's test

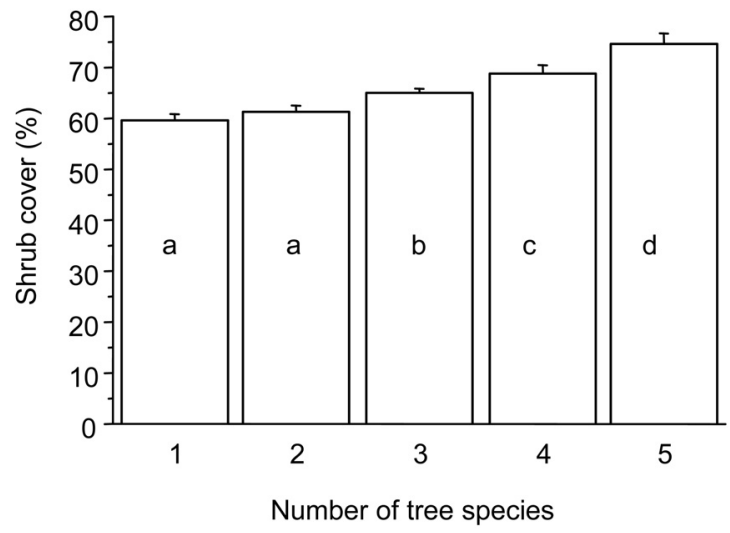

\subsubsection{Climatic and Lithologic Correlates}

To test for the effect of confounding environmental gradients, we selected three integrative parameters: climate type, bedrock type, and total spring solar radiation. Climate type and bedrock type were used as the main variables in regional environmental conditions. Total spring solar radiation was chosen as a measure of local environmental variation.

Each plot was assigned to one of the nine climate categories of the Thornthwaite index (Thornthwaite 1948). Climate had a significant effect on stemwood productivity (Table 4.2). The forests with the highest productivity were located in humid zones, while forests with the least production and the fewest tree species are located in semi-arid and arid zones (Fig. 4.5). Bedrock type had a significant effect on stemwood productivity of forests only before canopy closure (Table 4.2). The forests with the highest productivity were located in unconsolidated alluvium materials. Radiation had a non-significant effect on stemwood productivity. Therefore, our analysis reveals an emphasis on the influence of macro-environmental factors on forest productivity at the regional scale.

When we restricted the GLM analysis to stands located in humid climates or in warmer climates, tree species richness did not have a significant effect on stemwood production either $\left(F_{4,593}=0.57, P=0.69\right.$ for humid stands, $F_{4,969}=1.52, P=0.19$ for extreme stands). The model showed the same amount of variation (52-53\%), and the same variables were significant as they were when all stands were included in the analysis. 


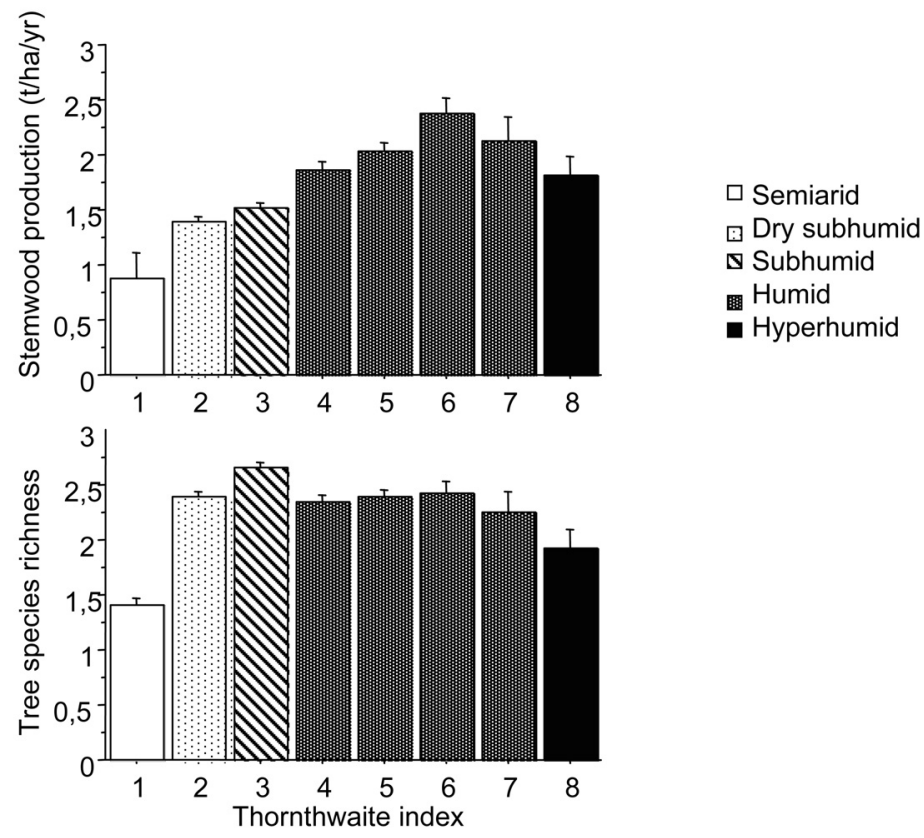

Fig. 4.5. Mean stand stemwood production (+SE) and tree species richness in relation to climate in Catalonia

\subsubsection{Species Richness-Productivity Relationships Within Forest Types}

That stand stemwood production increased with tree species richness was very striking when the dominant species was sclerophilous (ANOVA, $F_{4}$, $\left.{ }_{420}=7.05, P<0.001\right)$. When the dominant species was Quercus ilex, $Q$. suber, Arbutus unedo or the introduced Eucalyptus globulus, stemwood production in stands with four or five species was 19.6 and $45.8 \%$ greater, respectively, than in monospecific stands or those with two or three species (Fig. 4.6A). Stemwood production was also significantly different within conifer forests in which monospecific stands had the lower productivity (ANOVA, $F_{4,1362}=5.32$, $P<0.001$; Fig. 4.6B). Stemwood production was not significantly different between forests dominated by deciduous species (ANOVA, $\mathrm{F}_{4,291}=0.34, P<0.85$; Fig. 4.6C).

When we conducted a GLM for sclerophilous and conifer forests with the same forest structure and environmental variables as for all stands, tree species richness no longer had a significant effect on stemwood production ( $F_{4,47}=0.74, P=0.57$ for sclerophilous; $F_{4,1240}=1.95, P=0.10$ for conifer forests). Stemwood production was dependent on tree biomass, stand age, and climate as for all plots. These results suggest that even within a forest type environ- 
Fig. 4.6. Mean stand stemwood production $( \pm \mathrm{SE})$ for forest dominated by sclerophilous (A), conifers (B), and deciduous (C) tree species in Catalonia. Different lowercase letters indicate significant differences over tree species richness according to Fisher's test
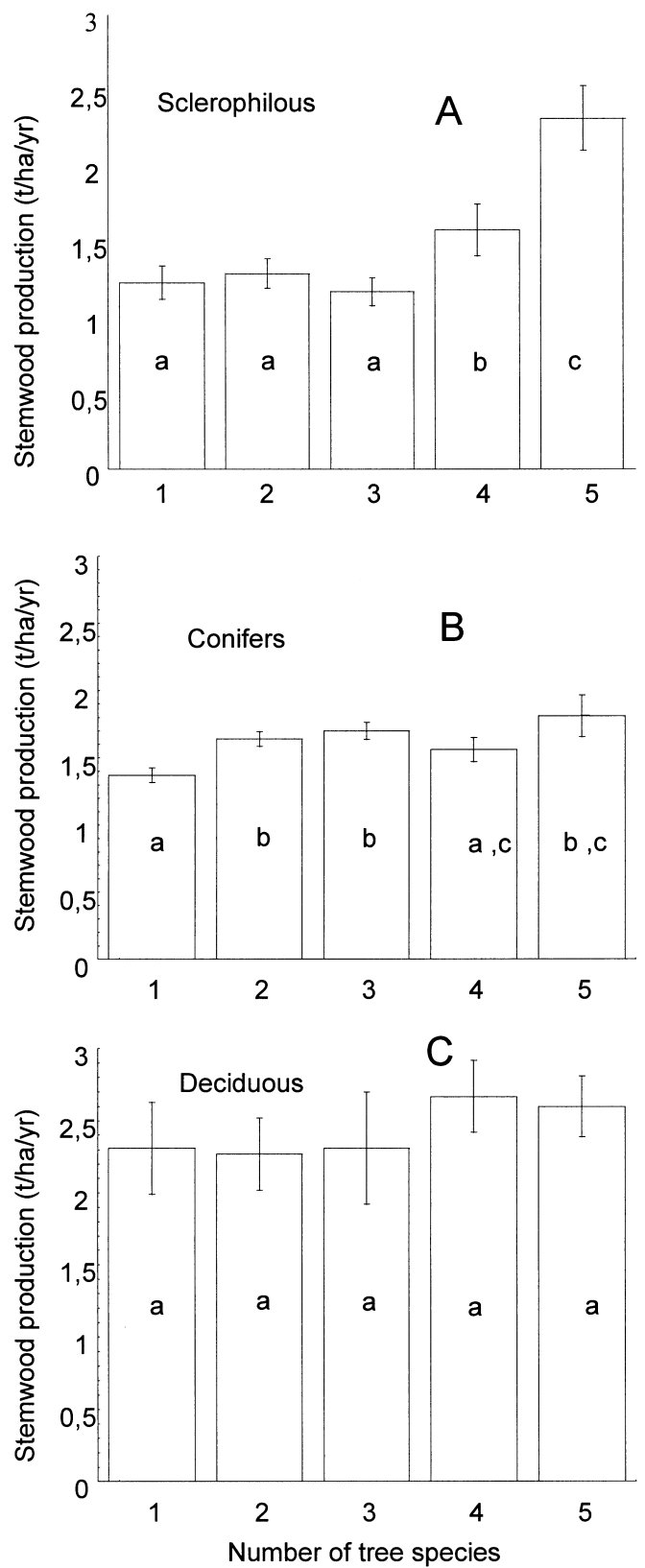
mental variables are more important in determining stemwood production than tree diversity. Only experiments conducted in the same site conditions and comparing plots with different tree species richness of the same functional type could determine if species richness has a causal effect on stemwood production.

\subsubsection{Management Considerations}

The IEFC included natural and semi-natural forests, plantations, and secondary woodlands, but unfortunately plots in the database were not classified into these categories. History and management have a great influence on tree diversity and productivity, and this is why climate sometimes does not predict tree diversity patterns (McGlone 1996). Our complete model had a weak predictive power (52-54\%) to explain differences in stemwood production, and this was probably due to the large effect of management practices on forest structure. For example, a different management of different productive sites can mask the diversity-productivity relationship. In addition, Catalan forests are young forests and the IEFC calculates tree growth for the last 5 years only. Hence, we do not have values for wood production over a longer period of time or within the whole rotation period, which would form the basis for management considerations from a forestry perspective.

Mediterranean forests have a long history of human intervention (e.g., tree planting, wood cutting, fire, pasture, charcoal production) that can mask natural spatial and temporal patterns of tree dominance and diversity (Rackham 1992; Villaescusa and Díaz 1998). In Catalonia, in general, monospecific forests have been deliberately favored over mixed forests. For example, some monospecific Pinus halepensis plots on poor soils might result from planting, while large areas of secondary forests dominated by P. sylvestris result probably from the harvesting of deciduous trees (mainly Quercus humilis), monospecific Q. suber stands have been favored for cork production (Aldomà 1988; Villaescusa and Díaz 1998), and so on. However, despite these efforts, in the last 20 years the extent of mixed forests has increased as a result of tree colonization of abandoned traditionally agricultural land, aforestation with fast growing species followed by reduced (low-intensity) silvicultural practices after planting, and a decrease in the commercial value of forest products (Raddi 1998; Villaescusa and Díaz 1998). We are also certain that in the last decades there has been no general management trend to maintain a certain tree basal-area value or to keep the shrub layer to a minimum in most forests, despite the fire risk that dense shrub cover can confer.

In general, Catalonian forests tend to have a low direct economic value, with only two thirds of the forests receiving any commercial value (Raddi 1998). Furthermore, the average timber quality is typically low: $90 \%$ of conifer timber is accepted in only the packing industry, and $21 \%$ of the over- 
all timber production is used only as a source of energy (mass production; Raddi 1998). Mixed forests of hardwoods and conifers in Catalonia appear to be less exploited commercially ( $58 \%$ ) than pure conifer forests ( $67 \%)$, but not significantly less than pure hardwood forests ( $58 \%)$. As a result, we cannot say that mixed forests are less exploited than monospecific stands in general. Furthermore, silvicultural practices and type of use of forests depend on geography, forest ownership, and size of properties (Aldomà 1988). In Catalonia more than $90 \%$ of the forested land is private and $85 \%$ of the properties are smaller than 25 ha. Hence, the properties are smaller than the minimum size required to be subjected to forestry policy planning (Peix 1999). Overall, human driven activities have a great effect on tree species productivity, tree species diversity, and community composition, but human activities have not been directly quantified in the IEFC database. Therefore, their influence on the forest productivity-diversity relationship remains to be tested.

\subsection{Discussion}

The relationship between tree diversity and productivity that can be observed at the landscape scale across forests and within forest types can be confounded by environmental factors, seral stage, and management practices, directly and indirectly (Fig. 4.7). The analysis of the IEFC shows that the positive relationship between species tree richness and stemwood production occurs in sclerophilous and conifer forests before canopy closure. These results suggest that the relationship is only found in early successional forests or in stressed forests (e.g., water or soil-nutrient-limited, rocky soils) in which the effect of having more tree species in a stand is additive to that of the dominant species. Since most of the Catalan forests are functionally young resulting from a decrease of high-intensity management in the last decades (e.g., end of charcoal production and agricultural land abandonment) or because they are at an early regeneration stage after disturbances (e.g., fire), we encourage maintaining tree species richness as a security to sustain forest productivity and spread the risk between species after disturbances (Pretzsch, Chap. 3, this Vol.). Furthermore, our analyses suggest that on average, at the short term, aforestation with a mixture of tree species might increase stand tree productivity more than doing so with a single tree species.

The study of the relationship between plant diversity and productivity has been approached by direct investigation of plant communities assembled in natural systems or by conducting experiments of plant assemblages. These approaches should be viewed as complementary. As seen in this study, forest inventories have the central caveat of confounding factors underlying the diversity-productivity relationship. However, such factors provide the oppor- 


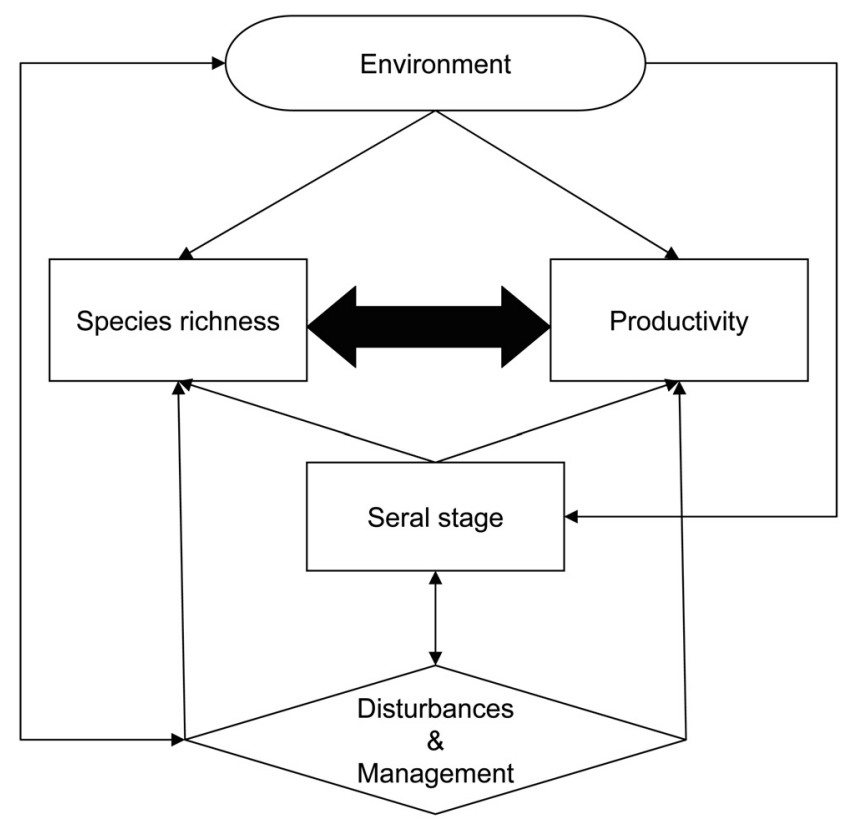

Fig. 4.7. Schematic representation of direct and indirect effects of environmental factors, seral stage, management, and disturbance on the diversity-productivity relationship in forests

tunity to compare natural systems within a matrix of biotic and environmental variation, from which specific hypotheses can be formulated that can be tested in more experimentally controlled conditions. In contrast, purposefully designed tree plantations provide causal information on the effect of tree diversity on tree production. However, due to the slow growth of tree species, several decades are needed to have a clear picture of the diversity-productivity relationship in tree plantations. There is also concern regarding how well experiments resemble the changes in species abundance and species losses that take place in real environmental and management conditions (Grime 2002; Schmid et al. 2002). From this perspective, most mixed tree plantations promoted by foresters contain tree varieties that have been genetically selected to have high production and to face environmental constraints (e.g., frost, drought). From the management point of view, well-designed experimental tree plantations are of interest to test which species mixtures are more productive. However, these plantations do not resemble natural conditions. Thus, to answer the central question of whether forest biodiversity increases forest productivity in the real world, experimental tree plantations should not select tree species at random from the local tree species pool, nor should the most productive species be selected, but selection should rather mimic the 
naturally occurring range of variation of tree species richness and abundance, taking into account that natural tree assemblages depend on a seral stage. These experiments should also consider the consequences of losing the tree species more at risk. Furthermore, as discussed by Schmid et al. (2002), experiments can investigate a broad spectrum of tree biodiversity components such as rarity, evenness, horizontal and vertical spatial patterns of species distribution within mixtures, age structure within species, etc.

\subsection{Conclusions}

The IEFC study case presented illustrates well some of the difficulties regional datasets raise in addressing the simple question of the effect of species mixtures on forest productivity. It is probably impossible to entirely divorce the association between species diversity and productivity from other biotic and environmental factors. Especially, in cultural landscapes such as large areas of Europe, disturbances and management have a great influence on forest composition and productivity (see Mund, Chap. 10, this Vol.). We advocate future analysis of forest inventories to include information on disturbance regimes (e.g., fire history, presence of domestic livestock) and silvicultural practices such as biomass removal either as wood export or understory clearings. In addition to inventory data collection to demonstrate causality, well-designed experiments with mixtures of naturally co-occurring tree species are needed. Up to now, such experiments in terrestrial ecosystems have mainly been limited to herbaceous assemblages.

Acknowledgments: We thank CREAF colleagues, Ch. Körner, M. Scherer-Lorenzen, E.-D. Schulze and an anonymous reviewer for stimulating comments and discussions. This paper is dedicated to those who conducted the IEFC fieldwork. The IEFC was financed by the "Departament d'Agricultura, Ramaderia i Pesca" and the "Departament de Medi Ambient de la Generalitat de Catalunya".

\section{References}

Aldomà I (1988) L'estructura de la superficie forestal a Catalunya. Quaderns d'Informació Técnica 2. Diputació de Barcelona, Barcelona

Anonymous (1992) JMP 2.0.5. SAS Institute, Belmont, CA

Assman E (1970) Principles of forest yield study. Pergamon Press, Oxford

Bengtsson J, Engelhart K, Giller P, Hobbie S, Lawrence D, Levine J, Vilà M, Weiner J, Wolters V (2002) Slippin' and slidin' between the scales: the scaling components of biodiversity-ecosystem functioning relations. In: Loreau M, Naem S, Inchausti $P$ (eds) Biodiversity and ecosystem function. Oxford Univ Press, Oxford, pp 209-220 
Bormann FH, Likens GE (1979) Patterns and process in a forested ecosystem. Springer, Berlin Heidelberg New York

Cannell MGR, Malcolm DC, Robertson PA (1992) The ecology of mixed-species stands of trees. Blackwell, Oxford

Caspersen JP, Pacala SW (2001) Successional diversity and forest ecosystem function. Ecol Res 16:895-903

Cuartas P, García-González P (1992) Quercus ilex browse utilization by Caprini in Sierra de Cazorla y Segura (Spain). Vegetatio 99/100:317-330

Currie DJ, Paquin V (1987) Large-scale biogeographical patterns of species richness of trees. Nature 329:326-327

Elliott KJ, Swank WT (1994) Changes in tree species diversity after successive clearcuts in the southern Appalachians. Vegetatio 115:11-18

Franklin JF, Spies TA, van Pelt R, Carey AB, Thornburgh DA, Berg DR, Lindenmayer DB, Harmon ME, Keeton WS, Shaw DC, Bible K, Chen J (2002) Disturbances and structural development of natural forests ecosystems with silvicultural implications, using Douglas-fir forests as an example. For Ecol Manage 155:399-423

Frivold LH, Frank J (2002) Growth of mixed birch-coniferous stands in relation to pure coniferous stands at similar sites in south-eastern Norway. Scand J For Res 17:139-149

Gracia C, Burriel JA, Ibáñez JJ, Mata T, Vayreda J (2003) Inventari ecològic i forestal de Catalunya. Mètodes. Ed. Centre de Recerca Ecológica i Aplicacions Forestals, Cerdanyola del Vallès

Gracia C, Burriel JA, Ibáñez JJ, Mata T, Vayreda J (2000-2002) Inventari ecològic i forestal de Catalunya. Ed. CREAF, Cerdanyola del Vallès (http://www.creaf.uab.es/iefc)

Grime JP (2002) Declining plant diversity: empty niches or functional shifts? J Veg Sci 13:457-460

Halpern CB, Spies TA (1995) Plant species diversity in natural and managed forests of the Pacific Northwest. Ecol Appl 5:913-934

Hector A, Schmid B, Beierkuhnlein C, Caldeira MC, Diemer M, Dimitrakopoulos PG, Finn J, Freitas H, Giller PS, Good J, Harris R, Högberg P, Huss-Danell K, Joshi J, Jumpponen A, Körner C, Leadley PW, Loreau M, Minns A, Mulder CPH, O’Donovan G, Otway SJ, Pereira JS, Prinz A, Read DJ, Scherer-Lorenzen M, Schulze E-D, Siamantziouras A-SD, Spehn E, Terry AC, Troumbis AY, Woodward FI, Yachi S, Lawton JH (1999) Plant diversity and productivity experiments in European grasslands. Science 286:1123-1127

Huston MA (1994) Biological diversity: the coexistence of species on changing landscapes. Cambridge Univ Press, Cambridge

Huston MA (1997) Hidden treatments in ecological experiments: re-evaluating the ecosystem function of biodiversity. Oecologia 110:449-460

Kelty MJ (1989) Productivity of New England hemlock/hardwood stands as affected by species composition and canopy structure. For Ecol Manage 28:237-257

Kelty MJ (1992) Comparative productivity of monocultures and mixed-species stands. In: Kelty MJ, Larson BC, Oliver CD (eds) The ecology and silviculture of mixedspecies forests. Kluwer, Dordrecht, pp 153-170

Kerr G, Nixon CJ, Matthews RW (1992) Silviculture and production of mixed-species stands: the UK experience. In: Cannell MGR, Malcolm DC, Robertson PA (eds) The ecology of mixed-species stands of trees. Blackwell, London, pp 35-52

Leathwick JR, Burns BR, Clarkson BD (1998) Environmental correlates of tree alphadiversity in New Zealand primary forests. Ecography 21:235-246

Loreau M, Naeem S, Inchausti P, Bergtsson J, Grime JP, Hector A, Hooper DU, Huston MA, Raffaelli D, Schmid B, Tilman D, Wardle DA (2001) Biodiversity and ecosystem functioning: current knowledge and future challenges. Science 294:804-808 
McGlone MS (1996) When history matters: scale, time, climate and tree diversity. Glob Ecol Biogeogr Lett 5:309-314

Mittelbach GG, Steiner CF, Scheiner SM, Gross KL, Reynolds HL, Waide RB, Willig MR, Dodson SI, Gough L (2001) What is the observed relationship between species richness and productivity? Ecology 82:2381-2396

Murty D, McMurtrie RE (2000) The decline of forest productivity as stands age: a model based method for analysing causes for the decline. Ecol Mod 134:185-205

Peix J (ed) (1999) Foc verd II. Departament d'Agricultura, Ramaderia i Pesca. Generalitat de Catalunya, Barcelona

Rackham O (1992) Mixtures, mosaics and clones: the distribution of trees within European woods and forests. In: Cannell MGR, Malcolm DC, Robertson PA (eds) The ecology of mixed-species stands of trees. Blackwell, London, pp 1-20

Raddi A (1998) El mercat dels productes forestals a Catalunya. Quaderns d'Informació Técnica 1. Diputació de Barcelona, Barcelona

Reich PB, Bakken P, Carlson D, Frelich LE, Friedman SK, Grigal DF (2001) Influence of logging, fire, and forest type on biodiversity and productivity in southern boreal forests. Ecology 82:2731-2748

Richerson PJ, Lum KL (1980) Patterns of plant species diversity in California: relation to weather and topography. Am Nat 116:504-536

Ryan MG, Binkley D, Fownes JH (1997) Age-related decline in forest productivity: pattern and process. Adv Ecol Res 27:213-262

Schmid B (2002) The species richness-productivity controversy. Trends Ecol Evol 17:113-114

Schmid B, Hector A, Huston MA, Inchausti P, Nijs I, Leadley PW, Tilman D. (2002) The design and analysis of biodiversity experiments. In: Loreau M, Naem S, Inchausti $P$ (eds) Biodiversity and ecosystem function. Oxford Univ Press, Oxford, pp 61-75

Singh SP, Adrikari BS, Zobel DB (1994) Biomass, productivity, leaf longevity, and forest structure in the central Himalaya. Ecol Monogr 64:401-421

Thornthwaite CW (1948) An approach toward a rational classification of climate. Geogr Rev 38:55-94

Tilman D, Reich PB, Knops J, Wedin D, Mielke T, Lehmann C (2001) Diversity and productivity in a long-term grassland experiment. Science 294:843-845

Trabaud L (1987) Fire and survival traits of plants. In: Trabaud L (ed) The role of fire in ecological systems. SPB Academic Publ, The Hague, pp 65-89

Troumbis AY (2001) No observational evidence for diversity enhancing productivity in Mediterranean shrublands? Oecologia 129:622-623

Troumbis AY, Memtsas D (2000) Observational evidence that diversity may increase productivity in Mediterranean shrublands. Oecologia 125:101-108

Vandermeer J (1989) The ecology of intercropping. Cambridge Univ Press, Cambridge

Vilà M, Vayreda J, Gracia C, Ibáñez JJ (2003) Does tree diversity increase wood production in pine forests. Oecologia 135:299-303

Villaescusa R (ed) (1993) Segundo Inventario Forestal Nacional (1986-1995). Cataluña. ICONA, Madrid

Villaescusa R, Díaz R (eds) (1998) Segundo Inventario Forestal Nacional (1986-1995). España. ICONA, Madrid

Waide R, Willig MR, Steiner CF, Mittelbach G, Gough I, Dodson SI, Juday GP, Parmenter $\mathrm{R}$ (1999) The relationship between productivity and species richness. Annu Rev Ecol Syst 30:257-300

Wardle DA (2001) No observational evidence for diversity enhancing productivity in Mediterranean shrublands. Oecologia 129:620-621

Weiner J, Thomas SC (2001) The nature of tree growth and the "age-related decline in forest productivity". Oikos 94:374-376 
Ecological Studies Vol 176, page proofs as of August 2004, Kröner, Heidelberg

Whittaker RH, Woodwell GM (1969) Structure production and diversity of the oak-pine forest at Brookhaven, New York. J Ecol 57:157-176 